\title{
Hybrid Taguchi method for optimizing flux cored arc weld parameters for mild steel
}

\author{
Satheesh, M. ${ }^{a}$, Edwin Raja Dhas, J., ${ }^{b}$ \\ ${ }^{a}$ Department of Mechanical Engineering, Noorul Islam Centre for Higher Education, Kumaracoil, Thuckalay, India \\ ${ }^{b}$ Department of Automobile Engineering, Noorul Islam Centre for Higher Education, Kumaracoil, Thuckalay, India
}

\begin{abstract}
A B S T R A C T
Flux cored arc welding has been applied in manufacturing industries for more than fifteen years. The quality of weld mainly depends on the mechanical properties of the weld, which in turn relays on the interaction of the weld parameters. This paper discusses the multi response optimization of weld parameters using grey based Taguchi method. Grey relational analysis was carried out to convert multi objective criterion into equivalent single objective function; overall grey relational grade, which is optimized by the Taguchi technique. Experiments are conducted using Taguchi's L27 orthogonal array. The weld parameters used in this study were welding current, welding speed, and arc voltage with bead hardness and material deposition rate as responses. Taguchi's Signal-to-Noise (S/N) ratio is computed based on their performance characteristics. Grey relational grade was obtained using Signal-toNoise ratio values of responses. Based on the grey relational grade, optimum levels of parameters have been identified. Significant contributions were estimated using Analysis of Variance (ANOVA). A confirmation test was conducted to validate the proposed method. This evaluation procedure could be used in decision-making to select process parameters for a welding operator. The proposed and developed method has good accuracy and competency with the predicted value enhancing automation and robotization.
\end{abstract}

\section{ARTICLE INFO}

Keywords:

Flux cored arc welding

Optimization

Process parameters

Grey based Taguchi method

Orthogonal array

*Corresponding author: edwinrajadhas@rediffmail.com (Edwin Raja Dhas, J.)

Article history:

Received 23 August 2013

Revised 24 May 2014

Accepted 2 June 2014 


\section{References}

[1] Aloraier, A., Ibrahim, R., Thomson, P. (2006). FCAW process to avoid the use of post weld heat treatment, International Journal of Pressure Vessels and Piping, Vol. 83, No. 5, 394-398, doi: 10.1016/j.ijpvp.2006.02.028.

[2] Parmar, R.S. (1999). Welding processes and technology, Khanna Publishers, New Delhi.

[3] Murugan, N., Parmar, R.S. (1994). Effects of MIG process parameters on the geometry of the bead in the automatic surfacing of stainless steel, Journal of Materials Processing Technology, Vol. 41, No. 4, 381-398, doi: 10.1016/0924-0136(94)90003-5.

[4] Raveendra, J., Parmar, R.S. (1987). Mathematical models to predict weld bead geometry for flux cored arc welding, Journal of Metal Construction, Vol. 19, No. 2, 31-35.

[5] Katherasan, D., Elias, J.V., Sathiya, P., Noorul Haq, A. (2012). Flux cored arc welding parameter optimization using particle swarm optimization algorithm, Procedia Engineering, Vol. 38, 3913-3926, doi: 10.1016/i.proeng. 2012. $\underline{06.449}$.

[6] Katherasan, D., Elias, J.V., Sathiya, P., Noorul Haq, A. (2013). Modeling and optimization of flux cored arc welding by genetic algorithm and simulated annealing algorithm, Multidiscipline Modeling in Materials and Structures, Vol. 9, No. 3, 307-326, doi: 10.1108/MMMS-03-2012-0008.

[7] Kannan, T., Murugan, N., Sreeharan, B.N. (2013). Optimization of flux cored arc welding process parameter using genetic and memetic algorithms, Journal for Manufacturing Science and Production, Vol. 13, No. 4, 239-250, doi: 10.1515/jmsp-2012-0040.

[8] Biswas, B.K., Bandyopadhyay, A., Pal, P.K. (2014). A study on quality of weld in flux cored arc welding process, International Journal of Precision Technology, Vol. 4, No. 1/2, 81-95, doi: 10.1504/IJPTECH.2014.060619.

[9] Moshat, S., Datta, S., Bandyopadhyay, A., Pal, P. (2010). Optimization of CNC end milling process parameters using PCA-based Taguchi method, International Journal of Engineering, Science and Technology, Vol. 2, No. 1, 92102.

[10] Liao, H.-C. (2006). Multi-response optimization using weighted principal component, The International Journal of Advanced Manufacturing Technology, Vol. 27, No. 7-8, 720-725 doi: 10.1007/s00170-004-2248-7.

[11] Gunaraj, V., Murugan, N. (1999). Application of response surface methodology for predicting weld bead quality in submerged arc welding of pipes, Journal of Materials Processing Technology, Vol. 88, No. 1-3, 266-275, doi: 10.1016/S0924-0136(98)00405-1.

[12] Satheesh, M., Edwin Raja Dhas, J. (2014). Multi objective optimization of weld parameters of boiler steel using fuzzy based desirability function, Journal of Engineering Science and Technology Review, Vol. 7, No. 1, 29-36.

[13] Jeyapaul, R., Shahabudeen, P., Krishnaiah, K. (2005). Quality management research by considering multiresponse problems in the Taguchi method - a review, The International Journal of Advanced Manufacturing Technolgy, Vol. 26, No. 11-12, 1331-1337, doi: 10.1007/s00170-004-2102-y.

[14] Taguchi, G. (1986). Introduction to quality engineering: designing quality into products and processes, Asian Productivity Organization, Tokyo, Japan.

[15] Peace, G.S. (1992). Taguchi methods: a hands-on approach, Addison-Wesley, Massachusetts, USA.

[16] Kumanan, S., Edwin Raja Dhas, J., Gowthaman, K. (2007). Determination of submerged arc welding process prameters using Taguchi method and regression analysis, Indian Journal of Engineering \& Materials Sciences, Vol. $14,177-183$.

[17] Kuo, C.-F.J., Wu, Y.-S. (2006). Optimization of the film coating process for polymer blends by the grey-based Taguchi method, The International Journal of Advanced Manufacturing Technology, Vol. 27, No. 5-6, 525-530, doi: 10.1007/s00170-004-2217-1.

[18] Tosun, N. (2006). Determination of optimum parameters for multi-performance characteristics in drilling by using grey relational analysis, The International Journal of Advanced Manufacturing Technology, Vol. 28, No. 5-6, 450-455, doi: 10.1007/s00170-004-2386-y.

[19] Hsiao, Y.F., Tarng, Y.S., Huang, W.J. (2007).Optimization of plasma arc welding parameters by using the Taguchi method with the grey relational analysis, Materials and Manufacturing Processes, Vol. 23, No. 1, 51-58, doi: $10.1080 / 10426910701524527$.

[20] Kamal, J., Ajai, J., Sandeep, G. (2010). Optimization of multiple-machining characteristics in wire electrical discharge machining of punching die using Grey relational analysis, Journal of Scientific and Industrial Research, Vol. 69, No. 8, 606-612.

[21] Muthu Kumar, V., Suresh Babu, A., Venkatasamy, R., Raajenthiren, M. (2010). Optimization of the WEDM parameters on machining Incoloy800 super alloy with multiple quality characteristics, International Journal of Engineering Science and Technology, Vol. 2, No. 6, 1538-1547.

[22] Balasubramanian, S., Ganapathy, S. (2011). Grey relational analysis to determine optimum process parameters for wire electro discharge machining (WEDM), International Journal of Engineering Science and Technology, Vol. 3, No. 1, 95-101.

[23] Fisher, R.A. (1970). Statistical methods for research workers, Oliver and Boyd, Edinburgh, United Kingdom. 


\title{
Uporaba hibridne Taguchijeve metode
}

\section{za optimiranje parametrov pri varjenju mehkega jekla z MAG varjenjem s stržensko žico}

\author{
Satheesh, M. ${ }^{a}$, Edwin Raja Dhas, J. ${ }^{\text {,** }}$ \\ ${ }^{a}$ Department of Mechanical Engineering, Noorul Islam Centre for Higher Education, Kumaracoil, Thuckalay, India \\ ${ }^{b}$ Department of Automobile Engineering, Noorul Islam Centre for Higher Education, Kumaracoil, Thuckalay, India
}

\section{POVZETEK}

MAG varjenje s stržensko žico se v industriji uporablja že več kot petnajst let. Kakovost zvara v glavnem zavisi od njegovih mehanskih lastnostih, ki pa so odvisne od medsebojnih vplivov parametrov pri varjenju. Članek obravnava optimizacijo z več odzivi parametrov pri varjenju z uporabo sive Taguchijeve metode. Izvedena je bila siva relacijska analiza za pretvorbo večkriterijskega opisa problema v enakovreden opis z le eno ciljno funkcijo; dobljena splošna siva relacijska stopnja je bila optimirana s Taguchijevo metodo. Eksperiment je bil izveden z uporabo Taguchijeve L27 ortogonalne matrike. Varilni parametri so bili: varilni tok, hitrost varjenja in napetost obloka, odziva pa sta bila trdota zvara in količina nanešenega materiala v časovni enoti. Taguchijevo razmerje signal/šum $(\mathrm{S} / \mathrm{N})$ je bilo izračunano na osnovi njunih značilnosti. Siva relacijska stopnja je bila dobljena $\mathrm{z}$ uporabo vrednosti razmerij signal/šum odzivov proučevanega sistema. Na osnovi sive relacijske stopnje so bile ugotovljene optimalne ravni parametrov. Signifikantni vplivi so bili ocenjeni $\mathrm{z}$ analizo variance (ANOVA). Predlagan pristop je bil potrjen s testnimi preizkusi. Predlagan pristop je lahko pripomoček operaterju pri odločanju izbire procesnih varilnih parametrov.

\section{PODATKI O ČLANKU}

Ključne besede:

MAG varjenje s stržensko žico

Optimizacija

Procesni parametri

Siva Taguchijeva metoda

Ortogonalna matrika

*Kontaktna oseba: edwinrajadhas@rediffmail.com (Edwin Raja Dhas, J.)

Zgodovina članka:

Prejet 23. avgusta 2013

Popravljen 24. maja 2014

Sprejet 2. junija 2014 